\title{
A SOCIO-COGNITIVE STUdY OF ETHNOCENTRIC DISCOURSE IN LYNN NOTTAGE'S SWEAT
}

Sanaz Bayat, Shiraz University, Iran, s.bayat@fgn.ui.ac.ir

Bahee Hadaegh, Shiraz University, Iran, bhadaegh@shirazu.ac.ir

Original scientific paper

DOI: 10.31902/fll.34.2021.11

UDC: $821.111(73) .09: 316.647 .82$

\begin{abstract}
Being some major problems of our contemporary world, racism and ethnocentrism demand persistent critical scrutiny. One oft-neglected aspect of these problems is how such prejudices are shared and communicated among the members of the dominant group. This study examines Lynn Nottage's Pulitzer Prize-winning play, Sweat (2015), as a dramatic representation of how racism and ethnocentrism are reproduced and communicated as a social cognition. To this aim, the study tries to employ Teun Adrianus Van Dijk's cognitively-based discourse analysis and focus on some micro-level aspects of racism as a social cognition rather as an abstract historical phenomenon. Contextualizing the play within its socio-historical moment, three trends of schematic attitudes and mental models regarding ethnocentrism_as Van Dijk's theory outlines_are identified from and studied in the play. The findings demonstrate the socio-cognitive dimension of the discourse of racism, particularly the way it is reproduced and communicated among the dominant in-group members. Moreover, the discussion offers some insight on Lynn Nottage's latest dramatic endeavor in a hard-hitting portrayal of the intersections of race, class, and political economy and in drawing attention to the real meaning of diversity and inclusion in contemporary America..
\end{abstract}

Keywords: Racism; Ethnocentrisms; Schemata; Deviance; Difference; Threat; Teun Van Dijk; cognitive study

\section{Introduction}

Racism and ethnocentrism have long been on a subtle relation with literature and literary criticism. This study engages in the exploration of how Lynn Nottage's Sweat is interested in unveiling the discursive and cognitive mechanisms in the reproduction of racism within a society. To this aim, in this study the theoretical views of critical discourse analyst, Teun A. Van Dijk, provide the methodological and theoretical proposal for a cognitively-based discourse analysis of racism and ethnic prejudice in Nottage's play. Van Dijk's work on racism draws some major lines of inquiry. First, what seems very important is his statement on the cognitive dimension of racism; i.e. the way ethnic prejudices are used 
and represented in memory and the way those representations can affect evaluations and thus interactions. His cognitive theory is based on the tradition of schema theory. Second, he clarifies the different dimensions of ethnic prejudice in discourse. On this level, he also examines the social and communicative constraints of discourse; i.e., the way discourse is formulated by social norms, values, purposes, and interaction strategies. Third, Van Dijk considers how the formulated discourse of ethnic prejudice is understood by recipients who are exposed to prejudiced talk and text.

A cognitively-based discursive approach to Nottage's drama provides a relevant field of application. Within this context, Burton argues "drama dialogue which sounds like naturally-occurring conversation [...], if used and analyzed as if it were a transcript of real conversation, is an extremely powerful heuristic device for the discourse analyst trapped into a way of seeing by other styles of data." (96). Sweat, Nottage's Pulitzer Prize-winning drama on the intersectioning of race, class, and politics, is about a group of steelworkers who are betrayed by the American dream. Jason (white American) and Chris (AfricanAmerican), their mothers Tracy (white American) and Cynthia (AfricanAmerican), and another worker Jessie (Italian-American) hold long friendships with each other. But as economic downturn impedes their least expectations about their job in Olstead, class and racial struggles devastate their friendships and they become incapacitated to love each other. Mindful of Van Dijk's thought, this study provides some insight on cognitive, social, economic, and discursive factors in the reproduction of racism which is also pictured in a drama by Nottage. Prefacing this study with a brief sketch of Van Dijk's theory of the discursive reproduction of racism, the study first discusses the structure of prejudiced discourse and then its cognitive and social functions. This ordering aims to make the discussion more accessible. In reality, these processes are fully integrated in what social members do and produce in thought and talk. Hence, there might be some cross references throughout the study.

\section{Structure of discourse}

The basic thesis of Van Dijk's theory is that prejudice is reproduced in society through discourse and to recognize and trace it, the structure of discourse must be examined. The analysis of the discourse structures unravels the strategies involved in the reproduction of racism. The different units of discursive structures are separated on different levels. Not only linguistic and text grammar structures but also knowledge schemata are measured. Considering the semantics of a linguistic approach, an analysis of the cognitive dimension of discourse 
also turns necessary. In Van Dijk's words "the implicit methods people use [in talk] are taken-for-granted forms of social knowledge" (“Dialogue as Discourse" 3:2).

\section{Sources}

According to Van Dijk's empirical research on the ethnocentric sources people are exposed to and use, the media is very much involved in spreading information about several topics including: "immigration of foreign groups", "general problems that are described as being the actual or possible consequences of immigration, such as housing, (un)employment, social services, and education", and "crime and deviance associated with minority groups" (125). The media has a vast scope, a variety of representational means and goals, and an "intermediary role" (40-41).

\section{Topics of conversation}

The topics frequently discussed in prejudiced discourse, the semantic macrostructures, are considered in Van Dijk's theory as "properties of global meaning of discourse" (47). By this he means that the semantic structures have a schematic nature. The stereotypical topics and opinions can be largely categorized into several groups: contact and information sources, national policies, social problems, work and unemployment, rights and duties, norms and cultural differences, and education (50-54).Van Dijk organizes these sets of topics into three thematic and cognitive groups of attitude schemata: "difference, deviance, threat" (p.58). The expression of ethnic opinions is likely to be controversial or contentious; therefore, they are backed up with safety strategies with specified functions. These strategies, as Van Dijk recognizes, include "argumentation, semantic moves, style, and rhetorical operations" (75).

\section{Cognitive frame}

To link discourse to its social structure, Van Dijk brings a "sociocognitive interface of both personal mental models and socially shared mental representations" to his approach (44). For different cognitive tasks, like interpreting an event, we retrieve a cluster of knowledge from memory; that is the schemata stored in memory about specific events or situations. "Schemata organize our knowledge about other people and other groups and their actions", Van Dijk reminds.(183) Another crucial notion in Van Dijk's theory is situation model, which is defined as the structure we designate for specific events in a setting. Moreover, every situation model has a structured form (for instance, an event has 
a setting, participants, etc.) which he calls situation model schemata. For our discussion, for example, ethnic biases are certainly a constituent part in a situation model of an encounter between an ethnic minority and an in-group member.

Van Dijk also draws attention to the function of attitude in social information processing. To him, attitudes are forms of social cognition and clusters of general knowledge which through a "process of instantiation" (189) are formulated into data required for a concrete situation. Attitude schemata serve us to participate in communication. For our discussion, as an example, we might have attitude schemata about groups of people; i.e., context free evaluation and understanding of a group of people whose individual features we do not know. As Van Dijk maintains, ethnic attitude functions as the "cognitive program" for "maintenance of in-group dominance, power, and exploitation, or the protection of interests or privileges" (194). The attitude schemata about specific groups or the group schemata are branched into different categories: appearance, origin, socioeconomic position, sociocultural properties, and personality characteristics. Often the schemata attitudes we hold overshadow the interpretation of many actions by the minority.

The discursive and cognitive strategies and functions spelled out above systematically operate in everyday impersonal communication colored by ethnic prejudice; as dramatized in Nottage's drama. One can notice how the discursive and cognitive dimensions confirm and support each other and make ethnicist consensus subtly possible.

Lynn Nottage's Sweat sets in the steel town Reading in 2000 and 2008. The play is an example of dramatizing the anxieties of an age and addressing the problems of a country at a moment in history. It is a microcosm of contemporary America and its racial and economic struggles. Nottage in a way, not unlike Shakespeare in his age, takes the history cycle as a dramatic means in order to explore changes in American history and its politics, and to address the themes of economic decay, sociopolitical anxiety, and cross-racial tension. Sweat is another instance of Nottage's legacy; i.e., "distilling historical segments into dramatic storytelling" (Williams 19).

Not only through its life-like stage settings, and costume, but also given its roots in interviews with people living and working in the place and time historically represented on stage, Sweat conveys a sense of authenticity and realism. Nottage transforms the intimate confabulation with a close friend living a few blocks away from her and the later interviews she carries in Reading, Pennsylvania into a drama of human pain, fears, relations and friendships. 
The play opens in 2008 in a parole's office where Jason and Chris are interrogated for a crime the roots of which take us gradually back to the year 2000. When the flashback to 2000 occurs, three women Cynthia, Tracy, and Jessie are presented. These friends have been on a perpetual sweat to make the ends meet by working in Olstead for more than a decade. Through the years they have gathered in the post-shift cozy bar, tended by Stan, to drink to each other, celebrate birthdays, and share workplace gossip. Over the course of the play, the characters' bar gatherings is haunted by anxieties over cutbacks in Olstead. Gradually, the friendly atmosphere is poisoned by exponential rage, blame, jealousy, and fear. This is partly grown when the rumors about layoffs advertising job places in Olstead are spread and when many of the workers, including Jason, Chris, Tracy, and Jessie, are locked out of work as a result of NAFTA policies. As a consequence of this policy, many of the machines and equipment in Olstead are shipped to Mexico where a large number of workers are pleased to work with lower salaries than what is given to workers in Olstead, Reading. This coincides with the plant decision to promote Cynthia, a black woman, to management. Her friends are overwhelmed by the sense of betrayal of their friendship. They assume that Cynthia is with 'them' (the authority in Olstead) and ignores her friends. Further, they are nudged by jealousy and prejudice about being ruled over by a black minority. Nottage develops tension forward to a point where the audience, who already knows a crime has happened, realizes the causes and condition of the crime. In a devastating moment (act II, Scene V) when Oscar, a Puerto Rican, is escaping from the structured rage of his white friends, Jason attacks him. Trying to protect Oscar against unrelenting Jason, Stan is hit in the head and paralyzed. His paralysis expunges the rage among them, but leaves them with an unmending fracture in their hearts.

Reading, Pennsylvania was once a prosperous city, but in Sweat we can witness how it is captivated by the economic recessions of early 21th century America. During the economic recession from 1989 to 2007 the United States experienced decline in economic well-being, employment rate, and labor income. This is true while the gap between black individual and everyone else consistently increases during and after recessions (Masterson, et al. 2). The minority group suffered the most finance shrink and was the target of racist and ethnocentric prejudices: double Jeopardy. Audre Lorde aptly describes the state of being a member of such economy system:

we have all been programmed to respond to the human differences between us with fear and loathing and to handle that difference in one of three ways: ignore it, and if that is not possible, copy it if we 
think it is dominant, or destroy it if we think it is subordinate. (285, second emphasis added)

Sweat boldly portrays the human cost of such programming and the combustive side-casting of economic depression and racial tension catalyzed by wrong policies.

\section{The News clips as chorus}

The News clips at the start of each scene in Sweat fulfill Nottage's twofold goal. Firstly, to represent how the economic status is preconditioning the events of her drama and propels the characters through what they do. In 2008, when the first scene of the play opens, the news announces 'the largest single day decline in stock market history' in the US as the Dow Jones Industrial Average falls.

Secondly, Nottage encourages the reader/audience to recognize the connection between the past and the present and to realize that the present racial discord goes back in time. She foregrounds the piece of news by stylistically positioning them in the start of the scenes. As the play flashes backward we get notified about further economic crashes and their consequences: think tank reports of the widening income gap, DJIA further fluctuates, protesters in WDC disrupt the World Bank Meeting, 200 people in Reading camp outside, taxes increase in Reading, and many emigrants return to their hometowns as job and housing availability decreases. The scene by scene accumulation of news pieces about the socioeconomic condition in year 2000 _by being stylistically placed in between the opening and ending scenes set in 2008_subtly indents Nottage's saying: "we are a country that lost our narrative" ("We Are a Country"). The news clips announce the old events which give impetus to the disaster the audience witnesses on stage. What the audience and the reader witness in the bar, is an old disease which metastasize down into long-lived friendships, identities, and dreams.

The news clips are; moreover, notable for bringing up some frequent topics about ethnic minority in the media. The media coverage of these topics is a potent source for many common attitudes about ethnic minority among people. In Sweat, although the characters seem hardly aware of the radio and TV News in Stan's bar; the news voice like an invisible sonic envelope suffuses them. The media creates the mental schemata upon which they stand in relation to the world and events they experience. The sonic envelop created through the news echoes the economic depression of the time, the income gap between the majority and foreign minority, and the welfare decline and emerging 
crime as the result of foreign immigration. Characters retrieve the knowledge schemata received through their experience to handle their everyday contact with the minority members in their groups. Yet, examining the role of media in the reproduction of racism is not the major line of argument in this study. Nottage locates the combustive repercussions of the piecing together of economic turbulence and racial tensions in different points in her play.

\section{Economic downfall, race, and class}

Nottage's conception of the economic crash hitting the people in Reading and so many other American states is the matter of immigration and racial tensions. In an interview she explains how in the conversations she was having with people in Reading (which later shape Sweat) "a lot of the subtext, unspoken was the white majority's discomfort with diversity and inclusion" ("We Are a Country") Historically, reading always has welcomed the immigrants, but facing with hardships the turn of events will change. Hence, what Sweat displays is how class and racial agitation chase the individual's struggle to make the ends meet, to survive.

In fact, the subtext and the unspoken Nottage recognizes in the series of conversations carried in Reading is the refraction of the cognitive schemata constructed, modified, refashioned, and oft-shared for and among the inhabitants of a world.

As earlier discussed, Van Dijk's empirical research recognizes issues such as foreign immigration, the consequences, and government policies regarding such immigrants as being frequently spread through public discourse of media and then reproduced in every day talk. Individual's attitude schemata which are highly influential on their ingroup and out-group interaction are created through situation models affected by their everyday experience. As said, similarly, in Sweat the media is partly building the blocks of social memory and schemata. However, other elements are also effective variations in formation of situation models. Important, for instance, is the impact of example models and situation models. The worker friends in Sweat see and hear about people who have worked their life on the similar lines in Olstead and have lost their dreams and youths in lieu of nothing. They are witness to lives "constituted by a perpetual wish for freedom that continually eludes the wisher" (Williams 18). Not only poorly paid, they have paid off with their family, health, and hope for their trust at and dreams about their country. It is now about more than twenty years passing from the day Jessie stepped into Olstead. Back then she wondered she would work for a year or two and then sets on a journey 
around the world "Istanbul, Tehran, Kandahar, Kabul, Peshawar, Lahore, Kathmandu. Places" (Nottage,2017, 66), she recalls. Stan, the bartender, is a live instance of the future waiting for Tracy, Cynthia, their sons, and others. Stan gets injured by a machine which the managing authority in Olstead did not care to fix. For two months he is confined in hospital, unable to move his toes and to walk. He has worked loyally in Olstead for twenty-years, but the only time someone from the company comes to the hospital to this loyal worker is the time a lawyer comes in order to make sure that Stan would not legally sue the matter. Freddy is another victim of the history of Olstead. After he is fined, he becomes addicted and burdened with loans and debt which take him the rest of his life to pay off. He decides to give an end to this life of him by setting his house on fire. His wife has already left the poverty stricken husband, but the dog is trapped in the burning house. Right after hearing the story about Freddy, Tracy thinks of the possible legal consequences, if she sets her house on fire too. Such and similar events and situations forms the situation models and schemata which is expected to be later retrieved in their dealing with concrete situations, with decisions and policies from Olstead. Nottage shows how the time and circumstances these people are within is like a vortex, as Stan understands in the hospital. It follows then, that Nottage epigraphs her play with Langston Hughes' voice:

0 , yes,

I say it plain,

America never was America to me, (Nottage,2017, iv)

The social and economic condition in Reading and the more personal events and experiences, construct the mental schema and model through which characters are cognitively programmed into what they do and how they perceive their world. As Van Dijk maintains "People not only build and use models of events in order to represent their knowledge about such events, but also in order to represent their opinions about them." (Van Dijk, Context Models, 192) Hit by the economic crisis, what makes the condition even more unbearable for the white characters is the covert prejudice that they are losing their job to foreign minorities and even because of them. The long-held friendship Tracy, Jessie, and Jason maintain with Cynthia, Oscar, and Chris belies the hidden rage they foster against their minority friends.

This prejudice and rage is divulged slowly and subtly early in the play. Van Dijk's notion of group schemata reminds that the individual's out-group communication is organized by attitude schemata organized generally into three principles "deviance, difference, threat" 
(Communicating, 58). These schemata might be about appearance, origin, socio-economic position, socio-cultural properties, and personal characteristics. In everyday interaction, one might understand and evaluate other's acts, words, and characteristics as an instance of the schemata one holds. In Sweat Nottage places some white and ethnic minority members into an old friendship and examines how in the hard times the group attitude schemata rise to dominate and despoil their trust and confidence, shared dreams and secrets, and adventures and goals. Prejudiced attitudes (hold mostly by Tracy, Jessie, and Jason), though obviously ignited by the financial downfall of the characters, are paly noticeable before the job and work struggles. However, momentous is the deadly effect of economic crashes on the flow of events to desolation.

Among the stereotypical ethnic attitudes frequently occurring in discourse and communication, according to Van Dijk, evidences of issues such as work and unemployment, social problems, and education can be traced in Sweat. Before exploring the first (work and unemployment) below comes a discussion of the other two in the play. What the study aims at is highlighting the instances through which Nottage showcases the possible reproduction of ethnic prejudice in present day society.

\section{ATTITUDE Schemata}

\section{Difference}

During the play Tracy joins in the accounts of two events relating to Cynthia and her husband Brucie. The first happens in act I, scene ii, when it is Tracy's birthday and Stan tells he was hoping to see Brucie there tonight. Cynthia lets Stan know how Brucie started messing with drinks after being locked out from work and how he changed terribly. So, much that on the Christmas day he steals Cynthia's presents and her expensive tropical fish. Finally, one day she loses her composure and gets into a horrifying quarrel with Brucie at home. While Cynthia is recalling all this, Tracy frequently breaks in: "told ya", "Listen to this_" (Nottage,2017, 28). Then as soon as Cynthia tells Stan how in that day at home, she "get[s] cuffed and fingerprinted" by the police, Tracy quickly jumps to fill Stan in of how she goes to "bail [Cynthia] out" (29):

CYNTHIA: Yes ...

TRACEY: Yeah, can you believe

it? I had to go down there

and bail her out. New

Year's Eve. I'm wearing

heels and a sequin dress. (29) 
Through these words Tracy is communicating and maintaining a positive self-presentation and a negative presentation of Cynthia. First, she reminds Cynthia of how she has warned her about Brucie. Then to further present a positive picture of herself and a negative view of the condition, she adds how she helped her friend. The semantic move of explaining the condition further helps her in approaching the effect while being protected from the unwanted inference to her possible prejudice. The rhetorical operation of permutation; i.e. the way she orders the pieces of information also sounds telling. She starts with the confirmative "yes", continues with an emphasized question, starts the next sentence with the pronoun "I" which further stresses positive selfpresentation, and next she goes with a single emphatic phrase "New Year's Eve". The lexicon further manifests the contradictory condition and how she has undergone trouble by the deviant behavior of a minority figure: "bail out", "go down", "heels", "sequin dress".

The second time Tracy shows interest in sharing a story about how their black friend and her husband behave differently from "them" is in Act two Scene three. This is after Cynthia's promotion and Olstead's policies have wretched Tracy out. As Van Dijk contends one common prejudiced attitude among white majorities about ethnic minorities is how sexually driven and violent they can be. The story Tracy brings up is reminiscent of this schematic attitude. In the bar and before others, Tracy humiliates Cynthia by recounting how years ago Tracy and her husband and Cynthia and Brucie go to watch Larry Holmes' boxing match. When after the fight they are invited to a very fancy backroom, a young woman "legs, ass, boobs, weave" (Nottage,2017, 90) with her clothes barely visible on her body "settles in next to Brucie" (90). The moment the young woman places her hand on Brucie's shoulder, Cynthia puts up a fight with the woman, the two "rolling around" (90) on the floor. Tracy explains that in bringing up the story she wants to remind how Cynthia's powerful character made her fight for what she loves and how she misses that Cynthia. Through the technique of explanation, Tracy avoids being referred to as holding prejudiced view of thee ethnic minority and their behavior. She continues that now she expects Cynthia to leave Olstead and fight with her friends and for them. But in fact, what is communicated and maybe she wishes to achieve through her speech is negative presentation of Cynthia as an AfricanAmerican; they are violent and socio-culturally deviant from "us". Through the linguistic knowledge schemata Tracy and others as language users share, she is aided in achieving the designed effect. Brucie, according to her, rolls "like a pro", is "drenched in luck. It was just dripping off of him", and "The chips were leaping into his hands." 
(89) The simile says he was just like a pro not a professional player. The verb "drench" is often used in passive voice in English grammar and connotes "negative excess". The passive voice, the simile, and the implication of the word "drench" rhetorically operate to convey how Brucie was ineffectual and weak in the game as he is to be later facing the young woman. Moreover, the image conveyed by "the chips were leaping into his hands", through the verb "leap into" and the subject position of "chips", is once again that of negative excess. It also implies some common attitudes about ethnic minority: they "eat all our food" (Van Dijk, Communicating, 324), they have "strange habits of eating" (218), "they are less clean" (209). Via this kind of linguistic gambling, Tracy reproduces the ethnic schematic attitude that "they" are different from "us", their behavior is abnormal, they need to learn from our example. This, for Tracy, seems not to suffice however. She goes on to explain how the young woman, the "chick" (Nottage, 2017, 90) "so gently" places her hand on Brucie's shoulder and:

CYNTHIA: Why are you telling this story?

TRACEY: This chick was in heat, and she ever so gently places her hand on Brucie's shoulder, like this. I look over at Cynthia-

CYNTHIA: Don't-

TRACEY: And-

CYNTHIA: No-

TRACEY: She-

CYNTHIA: Lord, help me-

TRACEY: Is wearing the look: Stone Age. Prehistoric. T-rex. And I know what it means, Brucie knows what it means, but this bitch doesn't. Boobs leans over and whispers something into Brucie's ear. That's it. You just grab this chick's tits, and dig your fingernails in as hard as you can. (90)

The adjectives Tracy uses to describe Cynthia's look and the words "grab", "dig", "fingernail" all schematically convey the sense of wildness, savagery, barbarity and vulgarism which often Blacks are associated with. Also considering the phonological level, the repetition of the sound $\mathrm{lg} /$ and $/ \mathrm{k} /$ intensifies the harshness. This shows how through the semantics, syntax, rhetoric, style, and even phonology ethnic prejudice could be conveyed through language and linguistic knowledge schemata.

\section{Education}

According to Van Dijk, some frequent attitude schemata about ethnic minority and their right to and pursue of education are as follows: 
"They [the minority] lower the level of education at school" (Communicating, 231)

"they cause problem at school" $(58,54)$

"they (immigrants) should learn (do not want to learn) English" (56)

"they are less intelligent [than us]" (209)

The prevalence of such attitudes causes consensus among many white people that the minority should not be favored in education and schooling opportunities. A similar attitude schema is highlighted by Nottage in Sweat.

Cynthia's son, Chris dreams of studying in Albright and has decided to save up for tuition by working double shifts. He wants to refuse the terrain of his parents and other victims of Olstead and its likes, where the machines' noise does not let them hear their own mind. Chris has long avoided talking about his plans for education and the fact that he is accepted in Albright, because his friend Jason makes fun of him. Chris does not mistake Jason's reaction. Once that he blurts out that he is saving up for tuition, Jason starts ridiculing his plan for going to school and his aspiration for being a different person:

CHRIS: Yeah. Starting in September. Yup! Plan on working double shifts. Put away a little something, you know, for tuition.

STAN: Good for you!

JASON: Wait ... Wait, no way. Dude, what the fuck are you saying?

Why didn't you tell me?

CHRIS: Cuz, I knew you'd make fun of me.

JASON: Of course I will. Whatcha gonna do? Teach history at Reading High for the next twenty years?

CHRIS: I might.

$\cdots$

CHRIS: That's cool. Good for them. But, I kinda wanna do something a little different than my moms and pops. Yo, I got aspirations. There it is. And I won't apologize.

JASON: You got aspirations? What is this, Black History Month?

CHRIS: As a matter of fact it is. You got a problem with that?

JASON: If we're being perfectly honest, I get a little tired of the syrupy commercials. Actually, it shouldn't be called Black History Month, it should be called "Make White People Feel Guilty Month." Right, Stan? (Nottage,2017, 42)

Albright, among the 100 best colleges for African-American students, is proud to have a high number of students from minority. This 
college is also cited for its friendly and fair treatment of the students of color both by faculty and students. But still there are barriers for the minority students. According to an online homepage which shares students' and other members' experience at Albright, having a social life or going to chapel, for instance, are problems for black students. Others also say that they did receive racist prejudice and comments. (Stoudt)

Chris has got aspiration for future, but it seems that Nottage tries to suggest he might possibly be haunted by racist prejudices. Nottage is very keen in delicately bringing up a reference to Black History Month just a few lines further. Jason sneeringly resembles Chris' expressing of his goals and aspiration to Black History Month. Black History Month is an observance happening annually in February in the United States which celebrates and remembers important people in the history of Black Americans. It also lays emphasis on teaching of the history of Black-Americans in public schools. (what Jason pointedly refers to as: "teaching Black history at high"). Since its initial phase Black History Month grew in popularity and has being celebrated in many educational centers. The fact that public schools are the main disseminators of Black History Month and the subtle link Nottage draws between Chris' inspiration for education and Black History Month echoes Derrick Bell's more or less unheard voice. In his "Brown V. Board of education and the Black History Month", Bell argues that the Super Court's 1954 decision in Brown V. Board of education "to end racial segregation and discrimination" (pars. 2) in the public schools in the United States has not improved much during the years.

That the Brown V. Borad decision has not been considered as implying equal educational opportunities for students of color, Bell believes, turns the decision to an equivalent of annual Black History Month celebrations. On a Saturday night in February Black people experience a "brief reprieve from the hard life", a night when they can do as they like without the white look over them, but we know, Bell laments, whatever they promise themselves on a Saturday night "would be disproved by the harsh segregated reality of Monday morning." (pars. 6)

It seems a mere pretense that the annual ritual of Black History Month can have a long-lasting and permanent effect on the stronghold of racism empowered throughout the year, Bell maintains. The public schools in America are widely responsible for disseminating Black History Month ideals, but fail to thrill the black people by fulfilling the implicit belief in the Super Court's decision, EQUAL educational opportunity.

Jason's remark about Chris' aspirations is telling of an often relinquished fact. Jason regards Chris' thought and words as a show of 
Black History Month and does not hesitate to bet that Chris will be soon back to the old place, to Olstead. This is how Nottage dramatizes the way racist prejudice could be cognitively and discursively legitimized and reproduced in everyday interaction.

\section{Job and Employment}

As earlier said, the place and the time Sweat stages is haunted by economic depression and competition for job opportunities. The characters have all in a way suffered from the economic downfall. Yet, what brings about even more trouble and vexes the relations is the managing position offered to Cynthia. Olstead decides to position someone from the line to as a managing place. Cynthia and Tracy are considered for the promotion. Finally, Olstead offers the promotion to Cynthia. The decision does not sound unintentional; given the fact that during the economic downturn in Reading and many other American cities ethnic minorities and women were the target of many job biases, including less employment and less salary. It is not unimaginable that planning for the upcoming layoffs and renegotiations of contracts which are not to the benefit and satisfaction of workers, Olstead managers desire to lessen their possible trouble with workers' complaint and protest. By offering Cynthia the position, they engage the workers into an ethnic war and make them less aware of imminent danger of Olstead's policies.

Immediately after Cynthia expresses her intention to apply for the position, she is faced with Tracy's "What?! Get outta here." (Nottage,2017, 36) A few lines earlier Stan asks Tracy if she wants to apply for the position and hears Tracy's "Me? No Fucking way". But soon after she hears Cynthia's decision to apply, she decides to apply for the position too.

Later, when Cynthis is promoted, Tracy clearly avoids her, does not sit next to her or answer her. Given the fact that highest level negative schemata are accessed first (earlier discussed), Tracy claims that Cynthia gets the promotion through as dishonesty and immorality. She claims that she could not get promotion because she did not give in to Butz, Olstead's grandson. By saying that, Tracy implies Cynthia's possible immoral sexual act which leads to her winning the position. This is a common situation schema about the Blacks: "they are sexually perverted." (Van Dijk, Communicating, 60) However, the fact is, as Macdougald pointedly puts, a black woman "does not maintain any moral standard which may be assigned chiefly to the qualities of race, any more than a white woman does. Yet", Macdougld asserts, "she has been singled out and advertised as having lower sex standards." (81). 
Furthermore, Tracy claims that Cynthia is given the promotion because she is a minority:

TRACY: You know how long I been working at the plant? Forget it . .. Never mind, it's not important . . But, I know the floor as good as Cynthia. I do. You wanna know the truth, the only reason I didn't get the job is because Butz tried to fuck me and I wouldn't let him, and he told everyone in management that I'm unstable. I'm not unstable. I'm like-

OSCAR: That's some shit.

TRACEY: Yeah. It sucks. And, I betcha they wanted a minority. I'm not prejudice, but that's how things are going these days. I got eyes. They get tax breaks or something.

OSCAR: I dunno know about all that.

TRACEY: It's a fact. That's how things are going. And I'm not prejudice, I say, you are who you are, you know? I'm cool with everyone. But, I mean . . . c'mon . . you guys coming over here, you can get a job faster than- (Nottage, 2017, 58)

In Tracy's dialogue we can see an example of argumentation move and the semantic disclaimers of apparent denial and apparent concession. Through the argumentation move Tracy gives a positive selfpresentation and a negative other-presentation. She believes that she knows the job as good as Cynthia but was not promoted because she keeps to her moral principles. She prejudicially claims that "they wanted a minority" but immediately denies her prejudice and by generalizing things (that's how things are going these days) she refers to an attitude schemata. Once more she presents herself positively (I 'm cool with everyone), but apparently concedes that it is a fact that the minority get our jobs. "they live out of our pocket" (Van Dijk, Communicating, 129)

Exponentially, the rage grows. Oscar informs Tracy of the flyers announcing that Olstead is hiring and the rumors spread about shipping the equipment and machines in Olstead to Mexico. The possible locking out of some workers, in order to hire Mexican employees with lesser salaries and to convince the workers to renegotiate their contracts, terrifies Tracy and others. Being already cross with Cynthia over the promotion, Tracy does not hesitate to saddle Cynthia with the imminent threat to them all. She willingly assumes that Cynthia knows about the plant's decision and has not informed her friends. She tries to win others over against Cynthia's honesty and to heckle and accuse her.

The rage they harbor against Cynthia is soon sublimated to Oscar, another minority figure who is never acknowledged by others but who is visibly present in all the scenes. Packing his stuff and leaving 
Stan's bar for a job in Olstead which offers no greater expectation than eleven dollars an hour, he is stopped by Jason. Jason and others, except Cynthia, have been jobless and penniless for months and regard Oscar as a concrete example of a minority stealing their job. Jason loses his composure when Tracy ignites his rage by saying that Oscar "is heading to cash your check" (109) and attacks Oscar. Stan tries to stop them but is hit in head. Later we understand he is paralyzed as a result.

Sweat boldly addresses the socio-economic interests that racism and ethnocentrism serve. The coalescent power of economic depression, together with interstitial racial tensions and class conflicts brings a painful aftermath to the friendship of a decade. We place Stan as the fulcrum of the play, because he stands for the pain, suffering, injustice, and perishing of humanity encumbered by the society and its class and race strongholds. Sweat stages the way the society peoples a book of suffering, yearning, and regret but cunningly provides an untrue index. Van Dijk ends his Racism and Discourse in Spain and Latin America with a call for all to "study the ways racism is expressed, enacted, legitimated and reproduced by the many forms and meanings of text and talk" (Van Dijk, Racism and Discourse, 163). This joint effort, he believes, combats racism and ethnocentrism. Living "in the interstices of the archive and repertoire" (Knowles 10), Sweat stages the call.

But what Nottage encourages us to conclude is how love and humanity can conquer the world, despite the dissonance which she captures in the society. Sweat shows that there are real differences between us; of age, sex, race, and class. But what separates us and makes us strangers are not the differences, but our failure to recognize them and our refusal to listen to the dissonance that results from our separation. As an African-American women, Nottage seems to be strongly holding and promoting the cause which Audre Lorde makes common with Third-World workers: "Blacks and Third-World people are expected to educate white people as to our humanity." (284) After the plight he is stunned by, Chris finds shelter in a rectory and in the Bible which he carries with himself. At the end, the love and humanity, friendship and commiseration that haunt Chris and Jason, haunt the reader and the audience as well, and flies up its way into the realm of being. In the last scene, Nottage stages what Marilynne Robinson once pointed at as her religion: "we are souls living among souls." (Robinson 04:28-04:31) 


\section{References}

Bell, Derrick. "Brown v. Board of Education and the Black Month Syndrome." 2020. Web. 19 May 2020 <http://www.edweek.org/ew/articles/1984/02/22/05340001.ho3.html>

Burton, Deirdre. Dialogue and Discourse. A Sociolinguistic Approach to Modern Drama Dialogue and Naturally Occurring Conversation. London: Rutledge \& Kegan Paul, 1980. PDF.

Van Dijk, Teun A. "Analyzing Racism Through Discourse Analysis: Some Methodological Reflections." In Race and Ethnicity in Research Methods. Eds. John. H. Stanfield II and R.M. Dennis. Vol. 157. Sage Publications, 1993. 02-134. Print.

. Communicating Racism: Ethnic Prejudice in Thought and Talk. India: Sage Publication, 1987. Print.

"Cognitive Context Models and Discourse." Congressional Record. Proceedings and Debates of the 102d Congress 137:84 (1991): 189-226. Print.

"Dialogue and Cognition". In Cognitive Constrains in Communication. Eds. Lucia Vaina and Jaakko Hintikka. Studies in Linguistic and Philosophy. Vol.18, (1984) 1-17. Print.

. "Dialogue as Discourse and Interaction." In Handbook of Discourse

Analysis. Ed. Teun A. Van Dijk. vol. 3. London: Academic P, 1985. 1-11. Print.

Racism and Discourse in Spain and Latin America. (Amsterdam: John Benjamins Publishing Company, 2005. Print.

Knowles, Scott. C. "A Chronology of Lynn Nottage's Production History." In a

Critical Companion to Lynn Nottage. Ed. Jocelyn L. Buckner. New York: Routledge, 2017.

Lorde, Audre. "Age, Race, Class, and Sex: Women Redefining Difference." In Words of Fire: An Anthology of African-American Feminist Thought. Ed. Beverly Guy Sheftall. New sYork: New P, 1995. 283-293. Print.

Masterson, Thomas, Zacharias, Ajit, Rios-Avila, Fernando, and Edward N. Wolff. "The Great Recession and Racial Inequality: Evidence from Measures of Economic Well-Being Levy Economics Institute, Working Papers Series." 2017, Web.2 December 2019 <http://dx.doi.org/10.2139/ssrn.2894528>.

Mcdougald, Elise Johnson, "The Struggle of Negro Woman for Race and Sex Emancipation". In In Words of Fire An Anthology of African-American Feminist Thought. Ed. Beverly Guy Sheftall. New York: New P, 1995. 8083. Print.

Nottage, Lynn. Sweat. New York: Theatre Communications Group, 2017.Print. "We Are a Country That Has Lost Our Narrative." 2018. Web. 2 December 2019 <http://thegurdian.com/stage/2018/dec/02/lynnnottage- interview-play-sweat- america>

Robinson. Marilynne. Marilynne Robinson on Faith, Capitalism and Democracy. 2014 video. 13 May 2016. < http://www.youtube.com/watch.>

Stoudt, Jennifer.P. "Being African-American at Albright." Web. 2 January 2020. $<$ http://www.albright.edu/reporter/fall>. 
Williams, Jay Austin. "On the Table: Crumbs of Freedom and Fugitivity_A Twenty-First Century (Re)Reading of Crumbs from The Table of Joy". In a Critical Companion to Lynn Nottage. Ed. Jocelyn Buckner. New York: Rutledge, 2017. Print.

\section{Socio-kognitivna studija etnocentričnog diskursa u drami Lin Notidž Slatko}

Rasizam i etnocentričnost kao glavni problemi našeg vremena zahtijevaju konstantno kritičko preispitivanje. Često zapostavljeni aspekat ovih problema je način na koji se predrasude posreduju među pripadnicima dominantnih grupa. Studija proučava komad Slatko, za koji je autorka Lin Notidž 2015. dobila Pulicerovu nagradu, sagledavajući ga kao pokušaj da se u dramskoj formi ponudi odgovor na pitanje o nastanku i komuniciranju rasizma i etnocentričnosti kao vidovima društvene spoznaje. Sa tim ciljem smo u radu pokušali da primjenimo Van Dijkovu analizu diskursa koja se zasniva na spoznajnom aspektu fokusirajući se na mikro aspekte rasizma kao društvenog, a ne kao apstraktnog, istorijskog fenomena. Imajući u vidu društveni i istorijski kontekst u koji je situirana dramska radnja, identifikovali smo tri trenda shematskih stavova i mentalnih modela koji se tiču etnocentrizma na način na koji to specifikuje Van Dijkova teorija. Oni demonstriraju društvenu i spoznajnu dimenziju diskursa rasizma, pogotovo u vezi sa načinima na koji se on reprodukuje i posreduje među pripadnicima dominantnih grupa. $U$ diskusiji smo ponudili uvid u najnovije ostvarenje autorke sagledavajući ga kao ubojiti portret odnosa između rase, klase i političke ekonomije koji skreće pažnju na istinsko značenje različitosti i inkluzije u savremenoj Americi.

Keywords: rasizam, etnocentričnost, shema, devijacija, razlike, prijetnja, Van Dijk, kognitivna studija 